\title{
The Use of Ceramic Water Filters in Improving the Microbial Quality of Drinking Water
}

\author{
Tshishonga M, Gumbo JR
}

\begin{abstract}
Water borne infections are the number killer of children under five years in developing countries. The main reason is the consumption of untreated drinking water. Here we report on the use of ceramic water filters in reducing Escherichia coli, a surrogate for pathogens in drinking water and can be applied in a rural household. For microbiological analysis, the two ceramic water filters, one from Mukondeni and the other one from Sese in Zimbabwe reduced the high microbial load of the raw water. The result showed that the counts as colony form units, of coliform in the purified water was zero and in raw water was too many to count; these colonies were probably removed by the ceramic water filter. The microbial counts in the purified water were zero colony forming units per $100 \mathrm{ml}$ and within the SANS 241 guidelines values. The ceramic water filters from Mukondeni and Sese were able to improve the microbial quality of the raw water. The Sese ceramic water filter was slow and thus further improvements are required in the composition of materials by increasing the saw dust component and reducing the clay component. Thus, ceramic water filters are suitable for use at household level.
\end{abstract}

Keywords - Ceramic water filters; rural communities; drinking water; microbial load

\section{INTRODUCTION}

South Africa and Zimbabwe are a water-scarce country and the demand on this resource is increasing due to population growth and increased industrialization [1]. Associated with this industrialization is overburdening of municipal sewage plants that discharge partially treated sewage effluent that contributes to river base flows and contamination of surface water sources [2]. The quality of drinking water is powerful environment determinant of health.

Drinking water quality management has been the foundation for the prevention and control of water borne diseases. In rural areas due to lack of awareness and maintenance, most of the families carry out the routine activities such as clothes washing, utensil washing, bathing cattle's, washing near to the ground and river water sources which is one of the reasons for contamination [3]. Close to 2 billion people over the world lack access to safe drinking water and estimated 2 million fatalities are linked to water borne infections [4]. Safe drinking water is very important in controlling and preventing many diseases.

Manuscript received June 28, 2017. (Write the date on which you submitted your paper for review.) This work was supported in part by the IP60 research incentive).

J.R. Gumbo is with the University of Venda, Department of Hydrology \& Water Resources.

M. Tshishonga is with the University of Venda, Department of Hydrology \& Water Resources as Masters student.
This is particularly well established for diseases such as diarrhoea, cholera, typhoid and paratyphoid fever, hepatitis and others. Ceramic water filters are affordable water purifications systems that are easily deployed at household level in order to provide safe drinking water. Recently in Harare, Zimbabwe there was an outbreak of typhoid fever and was attributed to contamination of groundwater source as a result of the recent rains [5-6]. The purpose of the study is to evaluate the microbial quality of filtered water using traditional ceramic water and a modern ceramic water filter.

\section{MATERIALS AND METHODS}

\section{A. Ceramic Water Filters and Water Sampling}

The modern ceramic water filter has been manufactured in a factory environment (Mukondeni, South Africa) and has silver nanoparticles incorporated in the clay matrix. Whereas the traditional ceramic water filter (Sese, Zimbabwe) was manufactured using traditional techniques of making ordinary clays pots but has the added advantage of having saw dust incorporated (no silver was added). The river water samples (raw) were then filtered through the ceramic water filters, hereby named, Mukondeni (CWF1), and Sese (CWF2) ceramic water filters. The raw and filtered water was then subjected to further microbial analysis. Turbidity was measured using turbidity meter, it was also measured in triplicate and the mean value was calculated.

This was done by investigating the presence of indicator organism E. coli. Membrane filtration method was used for $E$. coli pathogen indicators in the samples [8]. All agar plates used in this study were prepared according to the manufacture's specification (Heyns Lab Supplies), after preparation the samples were allowed to disperse into petri dishes and allowed to cool. All tests were performed in triplicates on $100 \mathrm{ml}$ volumes of samples were passed through $0.45 \mu \mathrm{m}$ pore size, $47 \mathrm{~mm}$ diameter Microsep filter paper.

The number of bacterial colonies on each of the specific plates were determined and expressed as colony forming units per $100 \mathrm{ml}$ (cfu/100 ml). Violet Red Bile Agar (VRBA) (Merck) was used for the enumeration. The colonies that turned red or surrounded by reddish precipitation zones were counted as E. coli.

\section{B. Data Analysis}

The results obtained were analysed comparing it to DWAF and SANS 241 [7] recommended water quality standards. The one-way ANOVA was used to determine the statistical 
differences between the raw and filtered water samples for each of the ceramic water filters at a significant level of $p<0.05$.

\section{RESULTS AND DISCUSSION}

The water sample for microbial analysis was obtained from a stream close to the University of Venda and was then passed through the Mukondeni ceramic water filter (CWF1) and the Sese ceramic water filter (CWF2) (Figure 1).

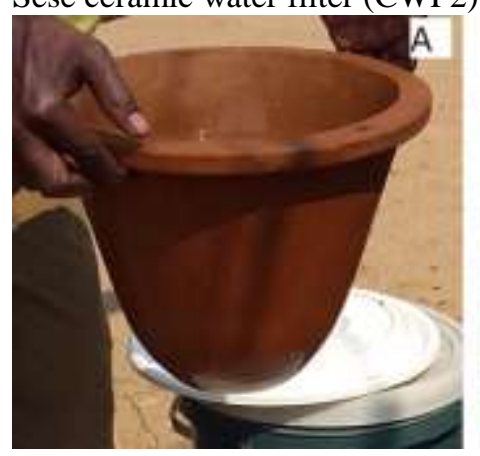

Fig 1: The ceramic water filters from (A) Mukondeni, Limpopo province of South Africa and (B) Sese, Masvingo province of Zimbabwe

Turbidity is the degree of cloudiness or clarity of water and this may be due to suspended and or colloidal material. WHO establishes that the turbidity of drinking water shouldn't be more than 5 NTU (Nephelometric Turbidity Units) and should ideally be below 1 NTU. To test turbidity, all that is needed to do is to collect the water sample and put it inside a vial that is inserted to a turbidity meter which measures the corresponding value of turbidity. The ceramic water filters, CWF1 \& CWF2, were able to reduce the turbidity $<1$ NTU in the filtered water as shown by the single factor ANOVA which showed that the raw and filtered water was significant different $(p<0.05)$. The ceramic water filters were found to be more effective and was able to reduce the turbidity of the river water. The study of Brown et al. [9] also confirmed the effective ability of ceramic water filters in reducing turbidity in raw water. However, the continuous use of the ceramic water filter results in blockages of the pores the trap pathogens during the filtration process and necessitates the cleaning of the ceramic water filters to remove the trapped contaminates [10]. Also, the suspended materials (turbid) in raw water supply may indicate the presence of pathogens and it is important in reducing turbidity.

The Mukondeni and Sese ceramic water filters were evaluated for the ability to remove and or reduce the microbial load of untreated drinking water (Figure 2). This was carried out by passing raw and contaminated water separately through the ceramic water filters and determining the levels of Escherichia coliform.

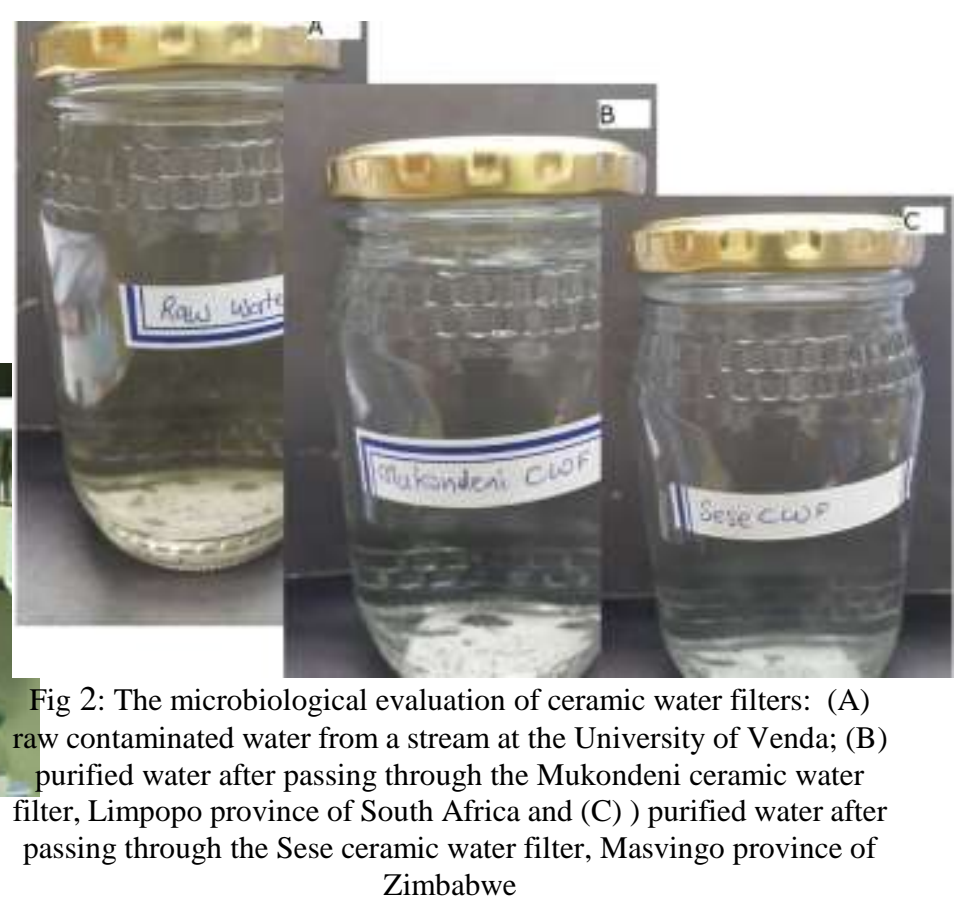

The results of microbiological organisms showed that there was a different between the raw water and filtered water (Table 1) as shown by the single factor ANOVA which showed that the raw and filtered water was significant different $(\mathrm{p}<0.05)$. The filtered water contained zero $E$-coli and this indicates that the ceramic water filter was able to remove all the microorganisms that were present in water.

\begin{tabular}{llll}
\hline $\begin{array}{l}\text { Ceramic } \\
\text { water filter }\end{array}$ & $\begin{array}{l}\text { BEFORE } \\
\text { FILTRATION }\end{array}$ & $\begin{array}{l}\text { AFTER } \\
\text { FILTRATION }\end{array}$ & $\begin{array}{l}\text { SANS } \\
\text { GUIDELINE } \\
\text { VALUES (cfu) }\end{array}$ \\
\hline Mukondeni & $>300$ & Zero & $1-10$ \\
Sese & $>300$ & Zero & $1-10$ \\
\hline
\end{tabular}

Data is average of triplicates

Escherichia coli are an indicator of faecal pollution. E. coli provides conclusive evidence of recent faecal pollution and should not be present in drinking-water [11](WHO, 2005). Thus, the presence of high Escherichia coli levels in water may indicate a higher risk of contracting waterborne disease, even if small amounts of water are consumed [12]. Thus, the ceramic water filters were able to reduce to zero the microbial load of the untreated raw water. The absence of $E$. coli in the purified water would translate to safe water that is suitable for human consumption. The Sese ceramic water filter was not impregnated with anti-microbial agents such as copper and or silver.

These anti-microbial agents are able to add value of improving the killing efficacy of the ceramic water filter [4]. A study by van der Laan et al. [13] showed that there was no difference in removing pathogens in ceramic water filters with silver and without silver nanoparticles. Thus, this implies that the ceramic water filters are effective in reducing pathogens but the presence silver is desirable. Though the presence of silver is desirable in the ceramic water filter the issue of cost becomes prohibitive since silver is expensive and would result in an expensive ceramic water filter beyond the reach of rural 
communities [14]. Also the silver leaches out in the ceramic water filter after two to three water filtration cycles resulting in no residual silver presence [15]. In this particular study the silver was analysed by was below detectable limits implying that the silver had leached out, below the 100 ppb WHO guideline for drinking water [10].

\section{CONCLUSION}

The ceramic water filters, Mukondeni and Sese, were able to improve the turbidity and microbial quality of drinking water. It was recommended that further research be carried out to improve the filtration rate of the ceramic water filter, since the Sese was very slow.

\section{ACKNOWLEDGMENT}

The study was supported by the research incentive ip60.

\section{REFERENCES}

[1] Osuolale, O., \& Okoh, A. (2017). Human enteric bacteria and viruses in five wastewater treatment plants in the Eastern Cape, South Africa. Journal of Infection and Public Health. https://doi.org/10.1016/j.jiph.2016.11.012

[2] Hicks, K. A., Loomer, H. A., Fuzzen, M. L., Kleywegt, S., Tetreault, G. R., McMaster, M. E., \& Servos, M. R. (2017). $\delta 15 \mathrm{~N}$ tracks changes in the assimilation of sewage-derived nutrients into a riverine food web before and after major process alterations at two municipal wastewater treatment plants. Ecological Indicators, 72, 747-758. https://doi.org/10.1016/j.ecolind.2016.09.011

[3] Gumbo, J. R., Dzaga, R. A., \& Nethengwe, N. S. (2016). Impact on Water Quality of Nandoni Water Reservoir Downstream of Municipal Sewage Plants in Vhembe District, South Africa. Sustainability, 8(7), 597. https://doi.org/10.3390/su8070597

[4] Ehdaie, Beeta, Chloe T. Rento, Veronica Son, Sydney S. Turner, Amidou Samie, Rebecca A. Dillingham, and James A. Smith. "Evaluation of a Silver-Embedded Ceramic Tablet as a Primary and Secondary Point-of-Use Water Purification Technology in Limpopo Province, S. Africa." PloS one 12, no. 1 (2017): e0169502. https://doi.org/10.1371/journal.pone.0169502

[5] Imanishi, M., Kweza, P. F., Slayton, R. B., Urayai, T., Ziro, O., Mushayi, W., ... \& Govore, E. (2014). Household water treatment uptake during a public health response to a large typhoid fever outbreak in Harare, Zimbabwe. The American journal of tropical medicine and hygiene, 90(5), 945-954.

https://doi.org/10.4269/ajtmh.13-0497

[6] Muzenda M, (2017). Zimbabwe Harare in Deep water over Typhoid outbreak. Daily Maverick of 22 January 2017

[7] SANS, (2011). Specification for drinking water SANS 2011 South African National Standards, Pretoria, South Africa.

[8] APHA, (1992) Standard Methods for the Examination of water and waste water, $18^{\text {th }}$ Edition. American Public Health Association, American Water Works Association, Water Federation Published by the American Public Health Association, Washington DC, USA

[9] Brown, J., Sobsey, M. D., \& Loomis, D. (2008). Local drinking water filters reduce diarrheal disease in Cambodia: a randomized, controlled trial of the ceramic water purifier. The American journal of tropical medicine and hygiene, 79(3), 394-400.

[10] Kallman, E. N., Oyanedel-Craver, V. A., \& Smith, J. A. (2010). Ceramic filters impregnated with silver nanoparticles for point-of-use water treatment in rural Guatemala. Journal of Environmental Engineering, 137(6), 407-415 https://doi.org/10.1061/(ASCE)EE.1943-7870.0000330

[11] Bain, R., Cronk, R., Wright, J., Yang, H., Slaymaker, T., \& Bartram, J. (2014). Fecal contamination of drinking-water in low-and middle-income countries: a systematic review and meta-analysis. PLoS medicine, 11(5), e1001644.

https://doi.org/10.1371/journal.pmed.1001644
[12] Department of Water Affairs and Forestry (DWAF), (1996) South African Water Quality Guidelines. Volume 2. Domestic Use. The Government Printer, Pretoria, South Africa

[13] Van der Laan, H., Van Halem, D., Smeets, P. W. M. H., Soppe, A. I. A., Kroesbergen, J., Wubbels, G., ... \& Heijman, S. G. J. (2014). Bacteria and virus removal effectiveness of ceramic pot filters with different silver applications in a long term experiment. Water research, 51, 47-54. https://doi.org/10.1016/j.watres.2013.11.010

[14] Simonis, J. J., Basson, A. K., \& Selepe, T. (2014). Removal of microbes to World Health Organization requirements using a locally developed, low cost, micro-porous, ceramic water filter. Journal of Water Sanitation and Hygiene for Development, 4(4), 620-624. https://doi.org/10.2166/washdev.2014.042

[15] Xia, Y., Jiang, X., Zhang, J., Lin, M., Tang, X., Zhang, J., \& Liu, H. (2017). Synthesis and characterization of antimicrobial nanosilver/diatomite nanocomposites and its water treatment application. Applied Surface Science, 396, 1760-1764.

https://doi.org/10.1016/j.apsusc.2016.11.222

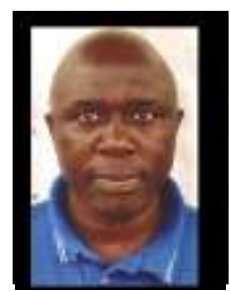

Professor Jabulani Ray Gumbo graduated with a PhD in Water Resources Management from University of Pretoria in 2007. He was awarded the second best student poster price at the $12^{\text {th }}$ International Conference on Harmful Algae in 2006 and the study was then published in the prestigious conference proceedings after a rigorous peer review process. This author became a Member (M) of International Society for the Study of Harmful Algae; International Mine Water Association; Water Institute of Southern Africa; Microscopy Society of Southern Africa and South African Council for Natural Scientific Professions. In 2008, he was appointed as a senior lecturer at University of Venda and in 2016 he was appointed as Associate Professor. He is the first or second author of more than 47 peer reviewed papers, conference proceedings and co-authored a chapter in a book. $\mathrm{He}$ acts as a reviewer for NRF in the fields of cyanobacteria and has been invited to be a reviewer for Ohio Sea Grant Proposal (USA); Journal of Applied Phycology (Australia); Bioresource Technology Journal (BITE) (USA); Journal of Freshwater Ecology (Britain); South African Journal of Science (SAJS) (South Africa) and African Journal of Biotechnology (AJB) (Nigeria). He lectures students at undergraduate and postgraduate levels in the fields of water treatment; water quality management; water law and institutions; rural water supply and sanitation; data information systems and water quality principles and he supervises several Honours, Masters and $\mathrm{PhD}$ students in the fields of water quality management; aquatic ecotoxicology and limnology and water treatment. In 2016 he and two other colleagues registered a patent on Defloridation of ground water rich in fluoride. 